Maurice A. Deane School of Law at Hofstra University Scholarly Commons at Hofstra Law

Hofstra Law Faculty Scholarship

2003

\title{
Gendered Workers/Market Equality
}

Daniel J.H. Greenwood

Maurice A. Deane School of Law at Hofstra University

Follow this and additional works at: https://scholarlycommons.law.hofstra.edu/faculty_scholarship

\section{Recommended Citation}

Daniel J.H. Greenwood, Gendered Workers/Market Equality, 12 Tex. J. Women \& L. 323 (2003)

Available at: https://scholarlycommons.law.hofstra.edu/faculty_scholarship/234

This Article is brought to you for free and open access by Scholarly Commons at Hofstra Law. It has been accepted for inclusion in Hofstra Law Faculty Scholarship by an authorized administrator of Scholarly Commons at Hofstra Law. For more information, please contact lawcls@hofstra.edu. 
Texas Journal of Women and the Law

Volume 12

\title{
GENDERED WORKERS/MARKET EQUALITY
}

\author{
Daniel J. H. Greenwood*
}

Abstract 323

I. Market Gender Constructs: Men Will be Men, and So Will

Women

A. The Unencumbered Worker: Liberation from the Family

Wage

B. Market Liberty vs. Status Slavery

C. Back to the State of Nature: The Market and Family

D. Adapting to the Market: The Freedom to Be a Man.

E. Market Equality Against the Family

II. Are Families Overprivileged? Exploring the Market Norm ............334

III. Complex Status Roles: Pedestals, Soldiers, and Aristocrats...........338

IV. Conclusion: Beyond Markets

Abstract:

Decades of feminism have freed women from many longstanding gender roles-less so, however, men. Women now wear pants, but men still do not wear dresses. Mothers of young children overwhelmingly work outside of the home, but male housewives remain rare. Tomboys have achieved some acceptance, but boys are still expected to be boys. Actresses needn't be sultry to be sexy, but actors are still taller, stronger and more silent than their sexual partners-except for Woody Allen.

Perversely, the confluence of women's entry into the workplace with the death of social democracy resulted in recreating the American worker as a gendered, unencumbered bachelor. Women have been freed to be men, and men have been freed to be single.

But someone has to wear the dresses, someone has to raise the children, someone has to go to work, someone has to take care of the old folks, and someone has to keep up the social calendar. So long as men are gendered into or out of some of these roles, women will be stuck with the rest, on overload. The next step of gender equality requires limiting market equality in order to loosen male gender roles.

* Professor of Law, S.J. Quinney College of Law, University of Utah. A.B. 1979, Harvard College; J.D. 1984, Yale Law School. 


\section{Market Gender Constructs: Men Will Be Men And So Will Women}

So far, gender equality has meant that women have become freer to be men; now the task is to free men to take on women's roles. Social support for childcare requires that it be transformed from women's work to citizens' responsibility.

Feminism and other civil rights movements have subverted gender status in an unexpectedly close alliance with the market and the very different agenda that the market encourages. Markets have a dynamic and a baseline of their own that make certain wrongs obvious and others hard to see. The market alliance powered civil rights victories. But it also limits the change: our markets continue to function within a strong culture of status.

Decades of feminism have freed women from many longstanding gender roles. Men, however, remain more constrained. Women now wear pants, but men still do not wear dresses. Mothers of young children overwhelmingly work in the paid labor market, but male housewives remain rare. Tomboys have won some acceptance, but boys are still expected to be boys.

The result is predictable. As women have taken on traditional male roles, they have continued to be responsible for female roles as well. ${ }^{1}$ Someone, after all, has to take care of the children and do the laundry and the cooking and the cleaning and the shopping and the entertaining.

In the upper echelons of the workplace, female executives have succeeded when, just like their male counterparts, they have put their careers ahead of family obligations and responsibilities. In the rest of the economy, women-now dominating both the routine clerical workforce and the part-time swing labor market-have also won the right to be treated as men. Instead of workplaces adapting to the needs of families, women have adapted to the needs of the workplace, taking lower pay and less interesting work in exchange for at least marginally greater time-flexibility.

The gender reverse, however, has not been true. In the upper echelons, men are still assumed to have a wife or to otherwise be willing and able to put their lives on hold when the office calls. In the less rarified

1. "Traditional" is a weasel word; in my experience usually it means "the way things were when and where 1 [i.e., the speaker] was a kid." The "tradition" of excluding women from the paid labor market is a recent innovation in most of the cultures and economies from which we trace our various histories. In my own family, my mother, my grandmothers, and at least some of their mothers all worked for pay. Only for a historical moment in the late 1950s and early 1960s did this seem odd. In many of the European peasant cultures from which many of us descend, women were often more likely than men to be market participants: the men were near-subsistence farmers and it was the women who took the surplus to market. Still, even if the details of gender roles seem unstable and shift over time and place, the fact of gender role separation is far more stable. 
strata, men remain in short supply in those sectors of the job market organized to accommodate a significant family role. Often this is due to more or less overt discrimination-it is not easy for a semi-skilled young man to get a pink collar job. Deindustrialization and the feminization of the back-office working class have left too many uneducated young men without any socially useful role at all-still barred from nurturing roles in the family, no longer needed in the workplace, little left to do but riot or rot in jail.

In short, much of the success of the feminist movement has been in allowing women to act like men.

\section{A. The Unencumbered Worker: Liberation from the Family Wage}

In one area, men are now treated more like women. The male "family wage" is dead. Male wages are still higher than female wages, but on an hourly basis the gap has shrunk dramatically, and in the bottom half of the income distribution almost entirely by a decline in male wages. ${ }^{2}$ In the great middle of the income distribution, men have lost the ability support a family financially, without gaining a new role in actual family activities.

But this male to female gender reversal can be seen the other wayperhaps it is more accurate to see the departed family wage as having itself been a gender reversal. Men were treated like women, as responsible caregivers and supporters of dependants. The demise of the family wage means that the employment market now treats men and women alike as single, unencumbered monads, each responsible for himself or herself alone. In short, family men and women alike have been reconstructed as single bachelors. ${ }^{3}$

In the old days (say back in the days of the Feminine Mystique), ${ }^{4}$ status rules limited the labor market and imposed a gendered division of labor. Women were barred from selling their labor on the same terms as men. Conversely, men were imagined to be free of responsibility for the cooking, cleaning, laundry, shopping, entertainment, and, of course, care for the children and the elderly. Husbands, with wives to live their lives for them, were free to work unencumbered by household responsibilities.

2. LaWrence Mishal et AL., The State OF WorkIng AMERICA 2000-2001, at 126-29 (2001) (showing that men's wages have declined dramatically in the bottom half of the income distribution, while women's wages have been flat in the center of the distribution and dramatically risen at the top; falling male wages account for approximately $65 \%$ of the closing of the gender gap).

3. See, e.g., Vanessa Fuhrmans, Company Health Plans Try to Drop FamiliesEmployees with Spouses, Kids Face New Surcharges as Employers Seek to Curb Costs, WALL ST. J., Sept. 9, 2003, at B1 (describing reductions in family benefits).

4. BetTy FRIEDAN, The FeminINe Mystique 15-32 (1963) (discussing the invisibility of the "problem that has no name"). 
The social reality has changed, but the market still prefers unencumbered workers. The two-spouse, one-income family is nearly extinct. Only a quarter of Americans live in a two-spouse household with children; ${ }^{5}$ of those, less than a third live on a single income. ${ }^{6}$ That is, only $9.5 \%$ of the population lives in a one-income, two-parent family with children. ${ }^{7}$

Over the last several decades, employers have found that they do not need to pay a family wage. With the breakdown of the status rules, workers can be paid something closer to their replacement cost as individuals, leaving families to make up the deficit by working longer hours. Thus, household incomes in the bottom $90 \%$ of the income distribution have stagnated in real terms for the past three decades, while the number of hours of paid labor has increased. ${ }^{8}$ Specifically, male wages

5. The proportion of households made up of two spouses with children (of one or both spouses) dropped from about $40.3 \%$ in 1970 to $24.1 \%$ in 2000 . U.S. CENSUS BUREAU, AMERICA's FAMILIES AND Living ARRANGEMENTS 2000, at P20-537, at 3, Fig.1. (June 2001), available at $\mathrm{http} / / / \mathrm{landview.census.gov/population} / \mathrm{www} / \mathrm{socdemo} / \mathrm{hh}-\mathrm{fam} . \mathrm{html}$. See also U.S. Census Bureau, DP-1: Profile of General Demographic Characteristics: 2000 [hereinafter TABLE DP-1] (indicating that $23.5 \%$ of households were made up of a married couple with children), available at:

http://factfinder.census.gov/servlet/BasicFactsTable?lang=en\&_vt_name=DEC_2000_SF1_ U_DP1\&_geo_id=01000US (last visited Nov. 3, 2003). Multiplying the number of married couple families with children $(24,835,505)$ by the average family size $(3.14)$ indicates that approximately $77,983,485$ people live in married couple with children households, which is approximately $27.7 \%$ of the total population $(281,421,906)$. Id. (author's calculations). See also Robert PutNam, Bowling Alone: The Collapse and Revival of American COMMUNITY 277 (2000) (reporting that in 1997, 26\% of adults were married with children at home).

6. U.S. Census Bureau, America's families and Living ARRangements March 2000, DeTAILED TABLES FOR CURRENT POPULATION REPORT, P20-537, available at $\mathrm{http} / / / \mathrm{www} . c e n s u s . g o v /$ population/www/socdemo/hh-fam/p20-537_00.html (indicating that one-third of two parent households with children have only one income: of 25,771,000 married couples living with children, 7,736,000 (30\%) had only one spouse in the labor force. An additional 774,000 (3\%) had one parent unemployed). See also MisHaL, supra note 2, at 98 (showing that for two parent households, the average number of hours worked in the top three income quintiles is more than full-time for each parent).

7. Derived from tbl.DP-1, supra note 5, by multiplying the number of one-income, two-parent families with children $(8,510,000)$ by the average family size $(3.14)$ to yield $26,721,400$ persons, or $9.5 \%$ of the total population $(281,421,906)$. Note that this includes recombined families, in which the two parents are not necessarily biologically related to the children.

8. MISHAL, supra note 2, at $121,124-28$ (demonstrating that despite gains in the late 1990s, hourly wages for each of the bottom five deciles were lower in 1999 than in 1973); tbl.DP-1 at 115 (showing that the increase in hours worked was the largest contributor to income growth in the last decade with the typical middle income couple working 3,885 hours per year; average annual hours worked increased from 1,758 in 1967 to 1,898 in 1998-three extra weeks of work per year). This was a period of greatly increased inequality in general. See Thomas PIKeTtY \& EMmanuel SAEZ, INCOME INEQUALITY IN THE UNITED STATES, 1913-1998, fig.13 (Nat'l Bureau of Econ. Research, Working Paper No. 8467,2001 ), available at http://www.nber.org/papers/w8467 (showing an increase in inequality during this period: the share of top decile of salary earners went from roughly 
have declined-rather dramatically in the lower half of the income distribution-and women have added paid labor to make up the loss. ${ }^{9}$ The unpaid labor of the housewife, of course, cannot simply disappear (although it can be reduced by eliminating the children that give rise to much of it). ${ }^{10}$

\section{B. Market Liberty vs. Status Slavery}

The first generation of civil rights law (for feminism, the Frontiero ${ }^{11}$

$25 \%$ during the $1947-67$ period to almost $35 \%$ in the late 1990 s).

9. MISHAL, supra note 2, at 124-28 (showing that hourly wages in 1999 for men were lower than in 1973 in the bottom six deciles and barely changed for the next three deciles). Middle income household incomes would have fallen but for increased work by wives. "[T]hirty years ago, middle income parents spent $3 / 4$ of their weeks in the labor market .... By 1998 that share had increased to $92 \%$." Id. at 93-109. The proportion of women in the labor force increased steadily from about $34 \%$ in 1950 to $60 \%$ and rising in 1997 . KRISTIN E. SMITH \& AMARA BaChU, WOMEN'S LABOR FORCE ATtaChMENT PATTERNS AND Maternity Leave: A ReVIEW OF THE LiteratuRe, fig.1 (Population Division, U.S. Bureau of the Census, Working Paper No. 32, 1999), available at http://landview.census.gov/population/www/documentation/twps0032/twps0032.html.

Conversely, the number of married women caring for children full-time dropped dramatically from roughly $30 \%$ of women as late as 1970 to about $14 \%$ in 1990 . JOHN P. Robinson \& Geoffrey Godbey, Time for Life, The Surprising Way Americans Use THEIR TIME 9-10 (1997).

10. In 1985, time diary studies estimated that women not in the workforce spent about 39 hours per week on childcare, housework and shopping; women in the workforce spent somewhat less: about 26 hours per week. ROBINSON \& GoDBEY, supra note 9, at 105, 334. Time diary studies consistently provide lower numbers than the other leading methodology, the National Survey of Families and Households. Id. at 100. Moreover, these figures presumably understate the number of hours women with children spend on these matters, since $32 \%$ of employed women have no parental responsibilities at all. Id. at 9 . For women with children, childcare took 3.6 hours per week for employed mothers and 7.0 hours for unemployed mothers in the 1985 study, differing from 2.7 hours and 9.3 hours respectively in 1965, in each case considerably less than the hours spent in "core housework" and shopping. Id at 105 tbl.3. Consistent with Robinson \& Godbey's general conclusion that Americans have adjusted to increased employment demands by reducing the number of children they have, these numbers apparently reflect an increase in the amount of time spent on childcare per child. Id. at 11,106 . However, their figures also suggest that children raised by single working parents receive essentially no primary childcare time. $I d$. at 106 . Robinson \& Godbey also contest the well-known claim that employed women simply add housework to their employment chores. In the aggregate, at least, women have reduced housework by reducing childrearing, and there is no "leisure gap." Id. at 4,54 . For the counter-claim, see ARLIE HochsCHILD, THE SECOND SHIFT: WORKING PARENTS AND THE REVOLUTION AT HOME (1989) (finding that women work longer hours than men and are more likely to compromise on career goals with part-time work). Regardless of whether women work more than men or vice versa, the proportion of families with children with a full-time caretaker has dropped dramatically (see supra note 5 and accompanying text), obviously leading to increased time pressures on those families, if not Americans as a whole.

11. Frontiero v. Richardson, 411 U.S. 677 (1973) (establishing strict scrutiny for 
principle of formal gender neutrality) fought for market over status. Markets in their ideal form are anonymous, anti-hierarchal, and anti-status. On the New York Stock Exchange, perhaps our paradigmatic market, there is no Jim Crow because there is no history. Black dollars are as good as white ones, new money is as good as old money; indeed, money laundering rules notwithstanding, criminal dollars generally are indistinguishable from honest ones. Products, too, are (or should be) priced according to the characteristics of the product, not those of the buyer or the seller. When a woman sells stock she receives the same price as a man; not even unconscious gender bias exists, because there is no way of identifying the seller. Markets, left to their own, do not respect traditional role boundaries, or indeed any traditions or histories at all. ${ }^{12}$ Yet while markets are antistatus, they are not egalitarian-markets will always redistribute from those with less market power to those with more market power. ${ }^{13}$

Early anti-discrimination law sought to import the market ideal of anonymity into the labor market, where anonymity is, of course, impossible. Its formal equality or meritocracy norm is simply the market norm of anonymity. Individuals ought to be treated according to their relevant characteristics - the money they have to spend or the product, labor, or skill they have to sell-disregarding other personal characteristics. We should be color-blind because the market is color-blind, treating black money the same as white money. Employees should be paid based on merit (i.e., at the rate they would receive in a hypothetical anonymous market) without regard to irrelevant status characteristics.

Race-blind meritocracy is the ideal of the stock market. Or to put it slightly differently, the first struggle of the civil rights movement was to replace feudal hereditary castes with capitalist markets. The first task of civil rights law, like the first generation of feminism, was to strike blows for the market. Minorities and women should be allowed to participate in the market as anonymous equals, no longer burdened by the status-based hierarchies of the past. For the first time, a woman willing and able to act like a man would be able to sell her services just like a man.

The first task of civil rights law, then, was to achieve that majestic equality of the law that, in Anatole France's famous words, forbade both rich and poor from sleeping under the bridges of Paris. ${ }^{14}$ For under our Ancien Regime as well, money alone was not enough to escape the

classifications based on sex).

12. This issue has been discussed by the author elsewhere. See generally, Daniel Greenwood, Beyond the Counter-Majoritarian Difficulty: Reconstructing the Law/Politics Distinction Through A Typology of Democratic Decision-making, 53 RUTGERS L. REV. 781, 827-31 (2001); Daniel Greenwood, Enronitis and the Fictional Shareholder (unpublished essay on file with author).

13. $l d$.

14. See Anatole France, The Red Lily 95 (Winifred Stephens trans., 1908) (1894). 
strictures of caste and gender. ${ }^{15}$ The market is a splendid tool for breaking down those restrictions, as even Marx recognized:

The bourgeoisie [through the market], wherever it has got the upper hand, has put an end to all feudal, patriarchal, idyllic relations. It has pitilessly torn asunder the motley feudal ties that bound man to his "natural superiors," and has left remaining no other nexus between man and man than naked self-interest, than callous "cash payment." It has drowned the most heavenly ecstasies of religious fervor, of chivalrous enthusiasm, of philistine sentimentalism, in the icy water of egotistical calculation .... The bourgeoisie has torn away from the family its sentimental veil, and has reduced the family relation to a mere money relation. ${ }^{16}$

In his characteristically overly deterministic way, Marx assumes, with Richard Epstein, that the market or the bourgeoisie will overcome caste by itself, without need of civil rights laws. ${ }^{17}$ One need not accept that optimistic view to accept the underlying logic of both Marx and Epsteinmarket ideals point towards the end of caste-based discrimination. ${ }^{18}$

\section{Back to the State of Nature: The Market and Family}

But stock is not worth more when it is owned by someone with higher expenses. A worker's productivity is not increased by the number of children he or she has at home. If anything, the opposite is true. The morality of the market demands that we ignore irrelevant outside characteristics, and it classifies children as both "irrelevant" and "outside"

15. See, e.g., Plessy v. Ferguson, 163 U.S. 537 (1896) (upholding Jim Crow laws); Patricia Williams, The Obliging Shell: An Informal Essay on Formal Equal Opportunity, 87 Mich. L. REV. 2128, 2138-43 (1989) (describing continuing realities of caste-based limitations); Patricia Williams, Alchemical Notes: Reconstructing Ideals from Deconstructed Rights, 22 HARV. C.R.-C.L. L. REV. 401, 408 (describing the continuing "struggle to set up transactions at arms' length ... [in] that creative commerce by which I may be recognized as whole, with which I may feed and clothe and shelter myself, by which I may be seen as equal-even if I am stranger. For me, stranger-stranger relations are better than stranger-chattel.").

16. Karl Marx \& Frederick Engles, Communist Manifesto 11 (Int'l Publishers 1976) (1948).

17. Id., and see RICHARD EPSTEIN, FORBIDDEN GROUNDS 3, 248 (1992) (advocating repeal of anti-employment discrimination laws on ground that they are unnecessary and unproductive, in part because discrimination is irrational and will not survive in a competitive market without the assistance of Jim Crow).

18. In sharp contrast to my view, however, Epstein identifies the market norm as the property principle that property owners have unrestricted discretion to refuse to deal. EPSTEIN, supra note 17, at 3. In my view, that property principle is a hold-over from feudal aristocratic ideals; markets, in contrast, begin with an ideal of anonymity in which only the product, not the seller or buyer, is relevant. 
for these purposes. (As Martha McClusky pointed out in this panel, having a wife at home does increase the worker's productivity, and in the old twospouse, one-income family, having a wife at home partly counterbalances the effect of the children. But a wife and children are two different things. One-third of children are being raised by single parents, grandparents or other relatives, unquestionably reducing the custodial guardian's market value. $^{19}$ The other children surely reduce at least the primary caretaker's productivity as well.)

From the market perspective, having children is no different than being black or having a taste for caviar or Porsches, or even being lazy or less competent. The market ideology says that a worker's pay should be related to what she produces, not what she needs or deserves. Thus, market equality is an equality of dollars and products. One citizen's dollars should buy as much as any other's, and one seller's products should sell for the same price as another's of similar quality. The market, therefore, is anticaste, anti-racist, and anti-feudal because it classifies the personal characteristics of buyers and sellers as irrelevant. (Citizenship based views, in contrast, start with a different baseline and therefore reach different results. The principle that we are all equal citizens suggests that as equal partners, we are presumptively entitled to equal participation (in some sense) in social product, including provision for our basic needs as citizens, education, housing, medical care, and minimum income. The market promises equal respect for equal dollars or equal product. Democracy, in contrast, promises equality of citizenship and equal respect for people. $)^{20}$

Support for families as caretaking units for children was never strong. Moreover it was closely linked to the anti-market status roles of the gender hierarchies. Under the pressure of the increased strength of market norms, and the first generation civil rights norms that largely tracked them, it simply collapsed.

\section{Adapting to the Market: The Freedom to Be a Man}

People, men and women alike, adapt to market demands as best they can. For all but the elite, the best way to be an unencumbered worker no longer is to be (or have) a husband with a wife at home. Husbands,

19. About $66 \%$ of children live in a two-parent family; about $23 \%$ live with a single parent. The balance live with other relatives $(8 \%)$, nonrelatives $(2 \%)$, with less than $.5 \%$ in group quarters or on their own. U.S. Census Bureau, Census 2000 Summary FILE 1 (SF I)TBl.P28, Relationship BY HOUSEhOLd TYPE fOR THE POPUlation Under 18, available at http://factfinder.census.gov (indicating that of $72,293,812$ children, only $47,682,383(66 \%)$ lived in a married couple family with its own children, and $16,812,254$ lived in a single parent household).

20. See Greenwood, Counter-Majoritarian Difficulty, supra note 12, at 790-803, 82731. 
encumbered or not, cannot earn enough to support a family. The second best solution is to drop responsibilities: to become unencumbered, without children, cooking or other avoidable responsibilities.

The failures and casualties are obvious-one-third of our poor are children; ${ }^{21}$ divorce rates reflect, at least to some degree, the economic reality that fathers are better off without children (even if that means without a wife as well); ${ }^{22}$ child birth rates are declining ${ }_{;}^{23}$ there is essentially no primary parenting time for the one-quarter of children raised by a single parent; ${ }^{24}$ and the disturbing reality is that the strongest predictor of poverty is dependent child care. ${ }^{25}$

The increase in single motherhood is in part a story of professional women unable to find suitable mates in a society where women and men alike still expect the male member of a heterosexual couple to be taller, richer, older and more accomplished. That is, while women have been

21. U.S. Census Bureau, Poverty IN THE U.S. 2001 1, 4, available at http://www.census.gov/prod/2002pubs/p60-219.pdf (stating that $35.7 \%$ of the poor are under the age of 18 years). Looking at the problem of child poverty another way, $16 \%$ of children are poor. Id. at 1 . This is considerably higher than the overall poverty rate, which is $11.7 \%$ using the Census Department definitions. Id. Moreover, the poverty rate for families headed by a female with no husband present is $26.4 \%$, as opposed to a rate of only $4.9 \%$ for married couple families and $19.9 \%$ for individuals not living with any relatives. Id. at 3 tbl.1 \& 7. $48.9 \%$ of children living in such female headed households are poor. Id. at 4 . Thus, both childhood and single parenthood (especially for women) strongly correlate with poverty. Bad as the current $26.4 \%$ poverty rate for female headed households is, however, it still reflects the vast improvements of the feminist success in using market norms to break down barriers to women's employment; in 1959, the poverty rate for female headed households was $49.6 \%$, almost twice as high as today. Id. at 21 tbl.A-1.

22. See, e.g., CTR. for Disease Control and Prevention, Cohabitation, Marriage, DIVORCE AND REMARRIAGE IN THE U.S., at 4 (2002), available at http://www.cdc.gov/nchs/data/series/sr 23/sr23 022.pdf (stating that "for a man, the retention of income combined with a reduction of family size [resulting from divorce] may actually result in an increase in his new household per capita income"). The divorce rate doubled between the 1950s and early 1960s, when it was around 2.1-2.6, and it peaked at 5.3 in 1979. CTR. For Disease Control and PreVention, 43 Monthly Statistics REPORT \#13, at 4 fig.2 (1995). The marriage rate, in contrast, has changed less dramatically and less consistently, but has been declining steadily since its relative peak of 10.9 in 1972 . Id. at 3 and fig.2. In 2001, the marriage rate was 8.4 and the divorce rate was 4.0. CTR. FOR Disease Control and Prevention, 50 Nat'l Vital Statistics Report \#14, at tbl.1 (2002), available at $\mathrm{http}: / / \mathrm{www} . c d c . g o v / \mathrm{nchs} / \mathrm{data} / \mathrm{nvsr} / \mathrm{nvsr} 50$ _14.pdf.

23. American fertility rates-i.e., births per 100 women aged 15-44-dropped steeply from a peak of 118 in 1960 to around $60-70$ by the mid-1970s and have been relatively stable since then. CTR. FOR Disease CONTROL and PRevention, 50 Nat'L Vital STATISTICS REPORT \#14, at 1 fig. 1 \& 2 tbl.A (2002), available at http://www.cdc.gov/nchs/data/nvsr/nvsr50 14.pdf. For $200 \mathrm{I}$, the fertility rate was 14.5 . Id. at tbl.1.

24. See supra notes 8 and 9 and accompanying text.

25. See, e.g., The NiChD Early Child Care Research Network, Poverty and Patterns of Child Care, in Consequences of Growing Up Poor 100-31 (Greg. J. Duncan \& Jeanne Brooks-Gunn eds., 1997). 
freed to be men, men are expected to be even more so. The increase in single motherhood is also a story of working class men who can no longer contribute to the family at all-due to the collapse of the industrial factory system, the decline of the family wage, and the drying up of nonprofessional jobs.

Young men are a central component of the organization of many societies. ${ }^{26}$ As a gross generalization, societies tend to take one of three approaches to their young men. Commonly, they segregate them, organizing them into all-male armies sent to fight one another and sometimes even to kill off significant numbers. ${ }^{27}$ Or they direct them to highly organized study or more organized employment and marry them off, enmeshing them in social contexts that will move them out of the dangerous rebellion of youth and into established paths. ${ }^{28}$ Or they jail them. ${ }^{29}$

26. Shakespeare commented in Julius Caesar about dangers of young men with a "lean and hungry look." William ShaKespeare, Julius CaESAR I, ii, 191. This view is widely shared by other observers as well. See, e.g., Sigmund FreUd, Civilization AND ITS DISCONTENTS 78 (Strachey trans., 1962) (describing primal myth of a band of brothers uniting to kill authoritarian father); CHARLes Henton COOLEY, SOCIAL ORganization 273$5(1909,1993)$ (describing the threat of "ambitious young men" and how stable societies coopt them into "supporting existing ascendancies"); TALCOT PARSONS, Age and Sex in the Social Structure of the U.S., reprinted in ESSAYS IN SOCIOLOGICAL THEORY 93, 102 (1954) (describing "youth culture" as having a "strong tendency to develop in directions which are either on the borderline of parental approval or beyond the pale," and in particular describing the early twentieth century German youth movements as "a generalized revolt against conventions" and an "important relation to the background of National Socialism").

27. See, e.g., Michael Foucault, Discipline \& PUNISH 210-211 (Sheridan trans., 1977) (describing use of military and other disciplines for social control); DAvID Maybury-Lewis, AKWE-Sharante Society 306 (1974) (describing "men's houses"); Robert Carniero, War and Peace, in Studying War: ANTHRopological PerSPECTIVEs 1218 (S.P. Rayna and R.E. Downs, eds., 1993) (describing "pervasiveness" of war from Ancient Greece through Roman Empire to the Middle Ages); Clark McCauley, Conference Overview, in THE ANTHROPOLOGY OF WAR 18 (Jonathan Hass et al. eds., 1990) (describing socialization of squad members in U.S. army to create internal solidarity).

28. See, e.g., Ctr. For Disease Control and Prevention, Cohabitation, Marriage, DIVORCE AND REMARRIAGE IN THE U.S., at 3 (2002), available at http://www.cdc.gov/nchs/data/series/sr_23/sr23_022.pdf (stating that married men and women exhibit less risky behavior than unmarried ones). "Less educated young men, however, have a lower probability of marriage in recent years." Id. at 4.

29. Foucault cites Bentham's Panopticon prison as a way of subjecting men to constant surveillance. MiChael FouCault, Discipline \& PUNISH 210-211 (Sheridan trans., 1977) (describing Panopticonism as a "state of permanent visibility that assures that automatic functioning of power ... polyvalent in its application"). He further contends that prison was also a critical way of forcing men into the early mercantile economy. $I d$. at 25 . Jail remains significantly important in controlling young men. For example, "[i]n June 1998 the number of adult men in prison or jail equaled 2.3 percent" in the United States, and those men were overwhelmingly young men when incarcerated. Lawrence F. Katz \& Alan B. Krueger, The High-Pressure U.S. Labor Market of the 1990's, 1999 BROOKINGS PAPERS ON ECONOMIC ACTIVITY 1, 40 (1999). 
We have not engaged in many wars in recent years; marriage still requires (as it usually has historically) that the male be able to bring in an income. Instead, we now seem to depend on jail to keep male unemployment at socially acceptable levels. The U.S. incarceration rate is the highest in the developed world. ${ }^{30}$ Adding that incarceration rate to our unemployment rate suggests that we are doing no better in creating jobs for young men than the famously rigid high unemployment economies of social-democratic Europe. ${ }^{31}$ We have merely replaced the dole with the lock-up for young men.

Men who have not graduated high school now have no social purpose at all. And the women they would have helped support are now on their own, supporting children and attempting to make a living in an economy that pays them only according to their own, presumably low, bargaining power.

Women, then, have won the privilege of being treated as men-as

30. Peter Slavin, Life After Prison: Lack of Services Has High Price, WASH. POST, Apr. 24,2000 , at A1.

31. See Crime: Locking Them Up, ECONOMIST, May 9, 1998, at 1 ("America now has 610 prisoners for every 100,000 people; Britain, by contrast has 110 prisoners per 100,000; France and Germany around 90."); see also Bruce Western \& Katherine Beckett, How Unregulated is the U.S. Labor Market: The Penal System as a Labor Market Institution, 104 AM. J. SOCIOLOGY 1030, 1036 (1999) (reporting 1993 incarceration rates of 80 per 100,000 for Germany, 519 per 100,000 for the U.S. in general and 1,947 per 100,000 for U.S. Blacks. Since prisoners are overwhelmingly male, male numbers would be close to double these.). Western \& Beckett, treating the incarcerated as unemployed, estimate that the U.S. unemployment rate, so redefined, would have been $1.9 \%$ higher in 1995. Id. at 1039 . Katz \& Kreuger, supra note 29 , in contrast, use the current definition of unemployment and attempt to estimate the effects of incarceration. Presumably, many current prisoners would not be in the labor force were they not in prison and therefore would not be counted in American unemployment figures: Katz \& Krueger's estimates suggest that including the prison population would increase the unemployment rate by only a small amount. Katz \& Kreuger, supra note 29, at 42-44 (estimating that the doubling of the prison population since 1985 has reduced the male unemployment rate by only .3\%). In contrast, the German Economic Minister reportedly claimed that the German "unemployment rate would be 1.5 percentage points lower if we had as many people sitting in jail as the U.S. has." Martin Waller, Werner Muller, Times London, Feb. 12, 2002, at 31. According to Katz \& Kreuger, Germany had a lower average unemployment rate than the U.S. in the 1960s, $1970 \mathrm{~s}$ and $1980 \mathrm{~s}$. In the $1990 \mathrm{~s}$, the German average unemployment rate was $0.8 \%$ higher than ours $(6.6 \%$ as opposed to $5.8 \%$ ) before adjusting for prison populations (or, presumably, for the more lenient understandings of labor force participation, resulting in higher reported unemployment, prevalent in Europe). Katz \& Kreuger, supra note 29, at 10 tbl.2. Western \& Beckett, who do not correct for labor force participation, show generally consistent results: reported U.S. unemployment has been lower than the European average since 1984, but when the incarcerated population is added, the U.S. unemployment rate is higher than the comparable European average in almost every year. Western \& Beckett, supra, at 1042, fig.2c. Even if only one-third of the prison population is included as unemployed, the U.S. and European results are very close, with Europe clearly ahead until 1993. Id. at 1042-43. 
unencumbered and fully-available workers in the market. Undereducated young men, in large numbers, have been freed from the workplace entirely, as employers have found women to be more pliable, skilled, and compliant in the "pink collar" sectors, and have transferred factory jobs overseas.

\section{E. Market Equality Against the Family}

The market norm seeks to treat us as equals in equal denial of our family obligations. Increasing numbers of Americans attempt to win a competitive advantage in this new arena by limiting those responsibilities-unencumbering themselves and selling their labor at prices reflecting only their individual needs. So far, the liberal program has helped them to do it.

But the problem still remains. Now that women have been freed to be unencumbered bachelors in the workplace, someone must still take care of the children. A bachelor's workplace does not address this problem any more than the old "family-man-with-wife-at-home" workplace did. Until the work of raising children, caring for the elderly, educating the young, and mentoring the adolescents is respected, honored, well-paid, and central, the struggle for gender equality will only have just begun. Gender equality means that men must be allowed and encouraged to take on women's work, and the market must be coerced (it cannot do it otherwise) into paying for families and not just monads.

In the market, family support starts with simple old-fashioned social democracy-separating the financial costs of child-rearing and dependant support from individual wages that the market seeks to set without regard to "external" responsibilities. Education (from preschool to university), retirement, medical care, family housing support, social insurance-these are the big expenses that separate the connected from the monads and that the market cannot properly account for in wages. We do a great job socializing the cost of roads, gasoline, farmers, Western water and ranchers. Now we need to extend that support to families.

And someone has to wear the dresses. In our culture, the necessary fundamental changes will not happen until boys can wear dresses and still win the girls. The girls are dating boys who have started coloring their hair, wearing earrings, even a bit of makeup. But tall, dark and silent wins the girl every time-who wants a sensitive guy (it is just a disguise for selfcenteredness) when a primeval hunter is around?

\section{Are Families Overprivileged? Exploring the Market Norm}

Are families already unfairly benefiting from existing legal norms? This paper has suggested that families ought to receive more, but perhaps 
they already get too much. Other scholars have provided strong evidence that, for example, the tax code benefits couples in which the husband works at a high paying job and the wife stays home. ${ }^{32}$ To begin with, it is important to distinguish between households (as defined by the tax code or standard econometric measures), couples, an image of a family as a husband and wife with 2.3 children, and "families" as I have used in this paper. While I use the term family for convenience, I do not mean to restrict the term to married couples with children.

Family is centrally about caretaking for non-income earning dependents who are unable to command market wages on their own. The key, then, is that the household contains one or more income earning adults who are paying for and otherwise taking care of one or more individuals who need care-paradigmatically children, but also disabled or retired adults.

Marriage alone is irrelevant. Two able-bodied, employable individuals forming a household, whether married or not, do not pose the issues that I raise here. If a couple decides to specialize, with one spouse (the husband) focusing on employment and the other (the wife) on homemaking, there is no special reason to be worried that the market will treat them unfairly. Presumably the husband will be more productive with a wife at home to live his life for him, and his pay should reflect that increased productivity. The market likely will pay this couple more or less than if they did not so specialize, but there is nothing particularly wrong with this market differential. Accordingly, this paper does not argue for the kind of tax benefits given to one-income married couples that Martha McClusky describes. ${ }^{33}$ Such tax benefits given to a small group of highly paid men with stay-at-home wives who are chiefly engaged in supporting the income earner's ability to earn his high wage do not count as family support under this paper's analysis - these tax expenditures are not going to support dependents who are unable to participate in the work force.

Similarly, while I use the term family for convenience to refer to a household with dependents, nothing in this argument requires or suggests that the household must be defined by blood or legal ties. It is the dependence that creates a family, not the blessing of a church or justice of the peace, let alone a Gilbert \& Sullivan-style notion that the

32. Bernie D. Jones, Single Motherhood By Choice, Libertarian Feminism, and the Uniform Parentage Act, 12 TEX. J. WOMEN \& L. 419 (2003).

33. Martha McCluskey, Caring for Workers: Beyond the Divides of Home/Market, Maternalism/Antimaternalism, and Dependency/Pleasure 2 (May 21, 2002) (unpublished manuscript, on file with author and to be presented at Gender, Work and Caretaking Session, Law \& Society Annual Meeting 2002) (describing and criticizing tax benefits given to highly-paid one-income couples). 
blood will out. ${ }^{34}$ With respect to adult couples, marriage is quite important (and should be available to a larger range of couples) precisely because it provides an easy way for two adults to signal to the world and to the State that they have entered into a position of mutual dependence, with a set of standard consequences for property relations and mutual care. But this is not the family I am talking about.

The issue may be restated as, "Do families-meaning households with dependents-already receive more than the market equality norm requires?" The answer is probably yes. The victory of the market equality norm has been widespread, but certainly not complete. So long as there still is old-fashioned status-based discrimination, it would be surprising indeed not to find remnants of the old system under which men were paid family wages to support their dependents at home. Of course, the old system was not tightly tied to family in this paper's sense, and neither are the remnants - tax benefits for one-income married couples and social security survivor benefits go to many individuals who are not families as defined in this paper.

More positively, the victory of the market equality norm has not entirely defeated other values. We still have public schools and public education, perhaps the most significant form of state support for the next generation. On the other hand, these institutions have been under attack at least since the beginning of desegregation, when "white flight" established the propriety of the principle of self-segregation. ${ }^{35}$ In a mobile, marketbased society, it proved easy enough for opponents of desegregation to simply abandon inner-city schools. Similarly, it is easy enough for the non-childrearing to self-segregate so as to avoid paying locally based school taxes. The effect, particularly for those children whose parent(s) are not able to move to affluent suburbs, has been a long decline in the quality of the public schools. ${ }^{36}$ Market norms combined with localized funding offer neither the means nor the justification for taxpayers to pay for the education of other people's children.

Similarly, market pressures, combined with a continuing residue of ideological support for the ideal of family, can lead to inconsistent and complex effects in the private sector. For the bulk of our population, male wages have dropped over the last generation. But for the professional elite, the experience has been different-wages at the top have increased and at

34. William S. Gilbert \& Arthur Sullivan, H.M.S. PINAFore (1878) (children switched at birth act according to hereditary character); WILLIAM S. GILBERT \& ARTHUR H. Sullivan, The Pirates of PenzanCe or the Slave of Duty (1879) (duty-bound pirates turn out to be Lords).

35. Milliken v. Bradley, 418 U.S. 717 (1974) (overturning inter-district busing order intended to ameliorate effects of white flight).

36. Christopher Lasch, Revolt of The Elites 45-47 (1995) (lamenting the ability of the modern elite to separate themselves from dependence on public services). 
the very top have soared. ${ }^{37}$ For highly paid employees, especially in an era of tax-phobia, untaxed benefits can be quite attractive. In the upper echelons of the private marketplace, family-based benefits, such as insurance, often still are not fully priced at marginal cost. Here too, however, the trends are anti-family-family support seems unfair to enough childless employees that there is significant pressure to eliminate non-market-cost based benefits. Each year brings another advance for the market norm in the form of, for example, higher fees for family insurance coverage or conversion to "cafeteria" style benefit plans that provide benefits proportional to salary rather than to need or caretaking. ${ }^{38}$

More fundamentally, whether or not family-based benefits are disappearing in favor of a market-based baseline of pay according to (market-assessed) marginal cost ultimately is beside the point. The more important question is whether market pay is the correct baseline from which to assess justice. The issue should not be whether families receive more or less than a pure market (if such a thing could exist) would pay. Rather, the issue is whether the market is the right baseline at all.

Under the market baseline, employees should receive pay proportional to the product they produce (and their luck), without regard to personal characteristics such as need, race, gender, desert, or dependents. Dependents, who do not produce marketable commodities, should receive nothing at all, except by courtesy of those upon whom they are dependent. Decent societies reject the market baseline precisely because they accept responsibility for all citizens, even those-such as children and the elderly - who are unable to sell their labor or their product in the market. Citizens are citizens based on membership, not on market-assessed marginal product. ${ }^{39}$

I have argued that the market equality norm gives families too little. A market, successfully barred from discriminating against women as women, will pay employees according to the value (as determined by the market) of their product. In general, familial obligations will be ignored by the market, just as race and gender are supposed to be. Caregivers will simply be forced to treat their caregiving as another form of consumption, and those dependent on them will be nothing more than objects of charity. But citizens of a democracy are entitled to more than charity, and decent societies accept that they have a responsibility to both the next and the last generation that goes beyond private consumption decisions by individuals who are moved by the young or old. Because we have an obligation to our

37. The Nation's Economic Boom is Fattening The Wallets of Top Corporate Executives, NewsDaY, Aug. 30, 1999, at A6.

38. See, e.g., Fuhrmans, supra note 3 (describing reduction of family benefits and increasing attempts to charge employees full marginal cost).

39. See supra text at note 18. 
fellow citizens, including children, we have an obligation to find nonmarket mechanisms to pay for their care.

\section{Complex Status Roles: Pedestals, Soldiers, and Aristocrats}

The description of the old status hierarchy and its newer partial replacement needs to be made somewhat less stark. Gender relations are complicated. Feminism began with a simple image of men on top and women on the botrom, but the reality was more polymorphic in society as in bedrooms. Women were not merely dependents, excluded from the central financially-rewarded relations of the marketplace in a capitalist society; they were also seen as, and even had some of the privileges of, a pre-capitalist aristocracy living off of the productive labor of others.

Moreover, high status roles are typically a burden as well as a benefit. The life of an aristocrat is not an easy one. Elaborate and highly artificial rules of dress and behavior-cossets and corsets, uncomfortable shoes, makeup, honor codes, and careful avoidance of the behavior of the people-characterize all aristocracies. As Thorstein Veblen pointed out long ago, it is the very difficulty of upper class consumption that makes it honorable. $^{40}$ To the extent that men were the high status group in the gender hierarchy, maleness brought with it a set of highly restricted role norms. Many of these rules-which I have summarized in short-hand fashion as "men don't wear dresses," but which more importantly have to do with male career-centeredness and social as well as economic barriers to male involvement in childcare as a primary life-focus-have barely been touched by the drastic changes in gender roles of the last decades. The roles of status do not die easily, even when they are artificial and dysfunctional-women continue to wear high-heeled shoes to be sexy, and even if real men sometimes can get away with eating quiche, they still bring home the bacon.

The net effect is that the stability of male role norms is overdetermined. On the one hand, as the economic privileges of men-the family wage and the largely effective bar on competition from womenhave broken down, many men have grasped the symbolic status-privileges of maleness as a last vestige of dignity. Boys will not act like girls because

40. Thorstein Veblen, The Theory of the Leisure Class: An Economic Study of InSTITUTIONS 40-50 (Modern Library ed., The Viking Press 1931) (1899) (arguing that the mark of the leisure class is "a conspicuous exemption from all useful employment," which requires that the leisured classes develop evidence that they are using their time nonproductively, such as "the knowledge of . . . correct spelling; . . . of the various forms of domestic music and other household art; of the latest proprieties of dress, furniture and equipage; of games, sports and fancy-bred animals. . . [T] [Te greater the consumption of time and substance impliedly involved in their acquisition ... the greater the resultant good repute."). 
that would be to step into a lower still status role.

On the other hand, women have hardly pressured to broaden the acceptable range of maleness to the same degree that they have fought to open the male world to women. As Aristophanes claimed in Lysistrata long ago, much of what boys do, they do in the belief that it will impress the girls. ${ }^{41}$ When the girls decide that they are not interested in dating the football captain or the soldiers, men will get the message eventually. What then leads women, still, to look for mates who are taller, richer and older than themselves, masculine in the most traditional sense, economic providers rather than homemakers, careers rather than carers? Why do men without the earnings to support a family remain unmarried?

The answers, again, must be as complex as the people who continue to form couples in which the man is taller. To some extent, it is a simple selfprotective response-in a society in which the old ways continue to be powerful, a traditional masculine male provider can protect. Couples who try to gender reverse face tremendous social resistance. There is no need to rehearse the difficulties the working wife will have in attempting to earn a "family wage." Even where it still exists, it is less available to women. Simultaneously, her husband will face all the classic problems of isolated suburban housewives, but without even the partially effective social support networks that the PTA, park benches, and churches have offered women. Then, as an empty-nester, he will return to the job market facing not only the same problem that women have for years (overcoming the objective proof of a lack of commitment to the careerist role the market rewards), but also an extra burden of prejudice for having not acted as a "real man." If staying home for a decade is devastating to a woman's career, it is doubly so to a man's. Many people, then, opt for the easier way, even while doing so reinforces the very social structures that constrained the couple in the first place.

Another aspect, perhaps less obvious and somewhat contradictory, stems from the complexity of gender status roles. Women also have not uniformly raced to shed the higher status parts of their traditional roles. On a fundamental level, the classic common law legal status of husband and wife is largely feudal, pre-capitalist, and extra-market. In the bad old days, women were excluded from the workplace and, in a capitalist society, consequently denied many of the privileges of income and wealth. Feminists have demonstrated the analogues between the status of wife and that of servant-dependency, limited legal personality, and so on. But the feudal, non-market character of gender relations is not merely one of master and servant. For a historical moment encompassing the middle of

41. ARISTOPHANES, LYSISTRATA 16 ([W]omen end war by agreeing on "total abstinence from the Prick.") (Nicholas Ruddell trans., 1991). 
the twentieth century, the image of the wife-and in the upper echelons of the economy, sometimes also the reality-was as much aristocrat as servant.

An ideal wife in an ideal marriage was not merely barred from the workplace but freed from it. The ideal stay-at-home housewife, like any proper aristocrat, left productive activity to others, focusing instead on increasingly complex and arcane consumption. In the image, servants before the First World War, or appliances and processed food later, took care of the work of homemaking. The suburban housewife, instead, was expected to maintain her appearance, supervise the operations, develop the style of the home and garden, entertain the guests, read and discuss literature (but not too seriously), dabble in music, volunteer in socially worthwhile projects, and attend church and coffee-klatches-much the same role that aristocrats have always held.

The life of an aristocrat, especially one who is living beyond his (or in this case, her) means-faking the life of the truly affluent without the resources to maintain it-is not an easy one. This was the lot of the aristocracy of suburban womanhood. Even among the more affluent, Jean Jacques Rousseau's attacks on the artificiality of upper class life are precisely analogous to the rebellion against bras, high heels, makeup, and women's forced withdrawal from economic life. ${ }^{42}$ The respectable drug addiction of the Valium "mother's little helper"43 era should be no surprise to readers of aristocratic novels; opium and alcohol long helped various aristocracies through the difficulties of courtly life. ${ }^{44}$ Still, if privilege has its price, most people seem to find status worth whatever it takes to achieve it.

The image, of course, only dimly connected with reality. We may have come closer for a brief moment to mass aristocracy than ever before, but nonetheless, a life of leisure, even in America, is a fantasy available only for a few. For one thing, children-who do not appear in the picture

42. Jean-Jacques Rousseau, The First and Second Discourses 146-48 (Roger D. Masters \& Judith Masters trans., Roger D. Masters ed., St. Martin's Press 1964) (1750) (arguing that art distorts natural morals); JEAN-JACQUES ROUSSEAU, EMILE 11, 15 (William Boyd trans., Teachers Coll. Press, 10th ed. 1962) (1762) ("From the beginning to the end of civilized life, man is a slave. At birth he is sewn up in swaddling bands and at death he is nailed in a coffin. All through he is fettered by social institutions.").

43. The Rolling Stones, Mother's Little Helper, on AFTERMATH (UK version only, Decca SKA 4786, 1966). See also Bruce Kennedy, The Tranquilizing of America, at http://www.cnn.com/specials/1999/century/episodes/06/currents (last visited Feb. 24, 2003) (on file with the author).

44. See generally Virginia Berridge \& Griffith Edwards, Opium and the People: OPIATE USE IN NINETEENTH CENTURY ENGLAND (1981) (describing opium use among upper classes); MARTIN BOOTH, OPIUM: A HISTORY (1996). 
of the trophy wife-require a good deal of effort, especially in the early years before they can be farmed out to school, television, and clubs. For another, even with modern appliances, the full image still requires servants to operate them. To be an aristocrat, even in this modest form, someone else must be the serf. Necessarily, then, most housewives could not achieve the full aspiration. Far more housewives worked hard to keep up the appearance of leisure than actually enjoyed the life of the image. When housewives must do the work of the servants instead of just telling them to do it, maintaining the appearances of propriety can be old-fashioned work, just unpaid. Women whose husbands no longer (or never) earned enough to keep them in leisure have to work quite hard to look like they are not working.

Still, the image of the housewife as aristocrat is critical to understanding the changes that feminism has wrought. The pull of the gender role image remains strong and explains some of the barriers to full gender equality that we face today. Most significantly, the image of wife as aristocrat partially explains some women's resistance to the changes in male roles that are necessary if there is to be room for greater gender equality.

To make room for women in the workplace, the vacuum at home must be filled. To pay for dependents, someone must earn more than simple marketability would mandate. The two problems are closely linked. Both require that we revalue "women's work." Caretaking must be something that men can do, honorably and prestigiously. And it must be something that society as a whole values enough to insist that markets that do not pay for it are markets that must be bypassed or changed.

\section{Conclusion: Beyond Markets}

So far, gender equality has meant that women have been freed to act like bachelors in a free market. The next step requires, on the one hand, that men be freed to act like women outside the market, and on the other hand, that women and men alike be able to overcome the limitations of market equality. The first problem is one of status and fixed gender roles. While the status limitations on female behavior have to some extent broken down, the status limitations on male behavior remain in place. Consequently, further progress in limiting gender role restrictions is impossible until men are freed as well as women. The second problem is the flip side of the great victories of feminism. Feminism has fought status with market. But market equality is not human equality. The victory of the market brings with it a new and perhaps more recalcitrant set of problems.

Feminism's largest victories have been victories of the market over feudalism in defining women's roles. The gender role barriers that kept 
women out of jobs have been broken if not entirely demolished. Most of the legal barriers to women entering the marketplace are gone. Exceptions-like the ban on women serving in combat roles in the military-become fewer each year. The barriers of prejudice and discrimination have diminished as well. Unlike only a few decades ago, today respectable economists can claim with a straight face that, controlling for labor market availability, skill levels, and the like, women are paid as much as men for comparable jobs. ${ }^{45}$ Of course such claims are still debatable-labor market availability in particular is a proxy for still powerful gender role differentiation. But such claims could not even have been made in 1965 . We are far closer to the market norm of equal pay for equal work than anyone could have predicted a remarkably short time ago. Market norms of "gender blindness" have defeated feudal norms of women's gendered status over and over again.

The basic idea of market equality is that a person's product can be bought or sold on the market without regard for the status or other characteristics of the person. It is the price and the product, not the seller or the buyer, that is important. Indeed, in our closest approximation to the market ideal, the stock market, the identity of buyer and seller are entirely secret. (The contrast to aristocratic, status-based regimes could not be stronger-medieval peasants, however rich, were barred from dressing like aristocrats and an aristocrat, however poor, had inalienable rights not dependent on market resources. The modern status-based regimes are similarly strict in restraining market equality. Thus, in Soviet Russia it is said that special lanes were reserved for the cars of party members and access to import stores was based not on ability to pay but on hierarchal status, while in Saudi Arabia even wealthy women may not appear in public alone.)

Market anonymity is generally a great advance over the overarching status hierarchies of feudal society. Low status is one of the great human evils, causing physical illness as well as misery. ${ }^{46}$ Decent societies reduce the gaps between high and low status individuals, but even more importantly, they offer many and multiple status hierarchies, so that those who are low on one scale can find others on which they are high. The great evil of creating "discrete and insular minorities" ${ }^{47}$ is that a single marker affects many aspects of life, breaking down the multiple and independent competitions of a free society.

The market anonymity principle promotes freedom in large part due to

45. See, e.g., Kathleen Parker, Women on the Verge of Wage-Gap Misinformation, $\mathrm{CHI}$. TRIB., Apr. 11, 2001, at 15.

46. See, e.g., Richard G. Wilkinson, Mind The GaP: Hierarchies, Health and HUMAN EVOLUTION 10-15 (2000) (describing health impacts of low social status).

47. United States v. Carolene Prod. Co., 304 U.S. 144, 152 n.4 (1938). 
its hostility to unified hierarchy. Producers good at one thing are not likely to be good at other forms of production, so there is room for many people to find a niche in which they can be top dog. Nor is excellence in producing for the market as stable or inheritable as aristocratic blood or Party membership. So markets offer more options and less stability than status-based alternatives. On the consumer side, those with more money will have more options than those without money, and this bears a certain resemblance to the aristocratic principle. But markets still provide more room for consumers as well; at least in the middle class many people can be high status consumers because there is no single defined hierarchy of consumption.

One step at a time, feminists have used market norms to overpower gendered restrictions on women's entry into the marketplace. ${ }^{48}$ But market entry is not enough. Markets will work toward equal treatment of market production - they will not, left to their own workings, create equality of persons or value non-marketable production, including, critically, nonmonetized caregiving. The next steps for feminism, thus, will be far more difficult; further progress conflicts with the logic of the market principle. Paradoxically, further integration of women into the labor market will require breaking down not only barriers to commodification but overcoming the logic of the market itself. We need room not only for female bachelors but for all workers with a life outside of the workplacecommitted, caregiving family members of all genders.

Left alone, markets will pay employees the minimum necessary to replace them; in a reasonably competitive market, employees should receive pay that is close to their marginal productivity in their next best job and to the marginal productivity of the person who would replace them in this one. Dependents only reduce those numbers (by reducing the employee's productivity). So, markets will not pay for dependents. Similarly, left to their own, markets will demand as much time as employees are willing to give to the job, and competition will assure that standard time demands usually will be set by the least encumbered. Families, in short, need time and money that markets, even in the absence of discrimination or prejudice, will not provide. Support for families means jobs with flexible and limited hours and incomes that reflect not only productivity but also dependents. These projects—unlike eliminating status based bars on female employment-will require overcoming markets, not just perfecting them.

48. Martha Ertman is taking this project in new and unexpected directions. See, e.g., Martha M. Ertman, Marriage as a Trade: Bridging the Private/Private Distinction, 36 HARV. C.R.-C.L. L. REV. 79, 81 (2001) (exploring "private law's potential to provide a metaphor that accounts for the range of intimate affiliations and counteracts the inequalities of the natural model"). 
